\title{
Leadership and team identification: Exploring the followers' perspective
}

\author{
Hendrik Huettermann $^{\mathrm{a}, *}$, Sebastian Doering ${ }^{\mathrm{b}}$, Sabine Boerner ${ }^{\mathrm{c}}$ \\ a Institute for Leadership and Human Resource Management, University of St. Gallen, Switzerland \\ b Center of Excellence "Cultural Foundations of Social Integration", University of Konstanz, Germany \\ c Department of Politics \&' Management, University of Konstanz, Germany
}

Keywords:

Leadership

Team identification

Qualitative research

\begin{abstract}
A B S T R A C T
This study investigates the influence of leadership on followers' identification with their work group. Adopting a qualitative research approach, it takes on the followers' perspective for inductively deriving leadership behaviors that pertain to the development of team identification. Based on in depth data from members of seven teams in the context of UN peacebuilding operations, four aggregate leadership dimensions can be identified that are conducive to members' team identification: providing guidance, encouraging involvement, role modeling, and administering teamwork. Accordingly, this study adds to the exploration of leadership behaviors relevant for team identification that have not been considered by extant research. The results may lay the foundations for future investigations on complementary effects of different leadership behaviors for fostering followers' identification with their work group.
\end{abstract}

\section{Introduction}

Research on members' identification with their work group has gained considerable academic attention in recent years (Ashforth, Harrison, \& Corley, 2008). Team identification has shown to play an important role for facilitating cooperation in teams and cushioning dysfunctional team processes (e.g., van der Vegt \& Bunderson, 2005), thereby leading to, for example, improved team performance and job satisfaction (e.g., Bezrukova, Jehn, Zanutto, \& Thatcher, 2009; Cicero, Pierro, \& van Knippenberg, 2007). Hence, strong team identification is considered to serve as "social glue" for teams (van Vugt \& Hart, 2004, p. 585) and as a crucial enabler for team members' willingness to achieve common objectives (van Knippenberg \& Ellemers, 2003).

Against this background, research has sought to identify factors that strengthen members' team identification. For example, perceived team status (Chattopadhyay, George, \& Lawrence, 2004) and levels of communication and interaction in the team (Postmes, Haslam, \& Swaab, 2005) have proved to be relevant in this context. One factor that has received particular attention for promoting members' team identification is leadership (van Knippenberg, van Knippenberg, De Cremer, \& Hogg, 2004, 2005). Sometimes referred to as "entrepreneurs of identity" (Reicher, Haslam, \& Hopkins, 2005, p. 556), leaders are believed to activate the collective level of followers' self concepts, thereby strengthening their identification with the workgroup and stimulating their team oriented efforts (Lord \& Brown, 2004; Shamir, House, \& Arthur, 1993; van Knippenberg \& Hogg, 2003).

However, examining extant research on the nexus of leadership and team identification, almost all studies investigate the effectiveness of predefined leadership styles (i.e., charismatic and transformational leadership; e.g., Pierro, Cicero, Bonaiuto, van Knippenberg, \& Kruglanski, 2005; Shamir, Zakay, Breinin, \& Popper, 1998, 2000) for promoting followers' team identification; only one study inductively explores other leadership behaviors that might be relevant for team identification, though exclusively

\footnotetext{
* Corresponding author at: University of St. Gallen, Institute for Leadership and Human Resource Management, Dufourstrasse 40a, 9000 St. Gallen, Switzerland. Tel.: +4171224 2377; fax: +41712242374.

E-mail address: hendrik.huettermann@unisg.ch (H. Huettermann).
} 
from the leaders' point of view (Sivunen, 2006). Hence, while the followers' perspective has already been more comprehensively investigated in other areas of leadership research (e.g., Bligh, 2011; Carsten \& Bligh, 2007; Shamir, 2007), it has been largely neglected in works on leadership and team identification (van Knippenberg et al., 2004). Yet, exploring the followers' perspective seems to be warranted in particular for two reasons. First, from a theoretical point of view, identification with social entities is considered to be a highly subjective process, involving deep rooted thoughts and beliefs on the part of the individuals that develop identification (Kreiner \& Ashforth, 2004; Pratt, 1998). Thus, adopting the perspective of those becoming identified (i.e., the followers) appears to be indispensable for exploring leadership behaviors relevant for team identification (van Knippenberg et al., 2004). Second, from an empirical point of view, existing studies have revealed only limited explanatory power; thereby, the amount of explained variance in team identification due to (charismatic or transformational) leadership ranges between 6 (e.g., Shamir et al., 1998) and 16\% (Kearney \& Gebert, 2009). ${ }^{1}$ Hence, an exploration of the followers' perspective may contribute to a more comprehensive understanding of which leadership behaviors are conducive to team identification.

Against this background, the aim of our analysis is to explore the followers' perspective and to scrutinize which leadership behaviors are perceived to be relevant for the development of team identification from the followers' point of view. In doing so, we may broaden the range of leadership behaviors relevant for team identification in addition to those identified by existing research. In line with the increasing number of qualitative studies in leadership research (Avolio, Walumbwa, \& Weber, 2009; Gardner, Lowe, Moss, Mahoney, \& Cogliser, 2010), we adopt an exploratory research approach, thereby focusing on formally assigned leaders that are (internal) members of their respective teams (see taxonomy of team leadership by Morgeson, DeRue, \& Karam, 2010). Based on qualitative data from interviews with members of seven work teams in the context of two United Nations (UN) peacebuilding operations, we inductively derive leadership behaviors that pertain to the development of team identification. As a result, we identify nine leadership behaviors that are conducive to members' identification with their work group. These leadership behaviors fall into four aggregate leadership dimensions: "providing guidance", "encouraging involvement", "role modeling”, and "administering teamwork".

Our results confirm several findings of previous research, for instance with regard to the importance of leaders' exemplary conduct for fostering followers' team identification. However, we also identify a number of leadership behaviors that have not been considered so far. For example, we find directive and participative leadership behaviors to complement each other in promoting followers' team identification. With our analysis, we thus echo the call by van Knippenberg et al. (2004) for broadening the leadership aspects studied in conjunction with team identification. The results of our exploratory analysis may lay the foundations for future quantitative studies that investigate the complementary effects of different leadership behaviors on team identification (van Knippenberg et al., 2004).

The remainder of this article is structured as follows: In the second section, we elaborate on the concept of team identification and we review the literature on the influence of leadership on team identification; on this basis, we specify the goal of our analysis. The third section provides an introduction to our empirical study, outlining our methodology and sample. In section four, we present the results of our qualitative investigation on the role of leadership behaviors for team identification. We conclude by discussing the results of our analysis.

\section{Conceptual background and literature review}

\subsection{Team identification}

Generally, social identification is defined as a deep, psychological, self defining affective and cognitive bond between an individual and a social entity (Edwards \& Peccei, 2007). Individuals are said to identify with a social entity when they (1) label or categorize themselves as members of it, (2) define themselves with the same characteristics used to define the social entity (e.g., values, norms, attitudes, etc.), and (3) feel psychological attachment and a sense of belonging to it (Dutton, Dukerich, \& Harquail, 1994; Pratt, 1998; Tajfel \& Turner, 1986; van Knippenberg \& Ellemers, 2003). Hence, through the process of identification with a social group, an individual comes to hold a social identity as "[...] that part of an individual's self concept which derives from his knowledge of his membership of a social group (or groups) together with the value and emotional significance attached to that membership" (Tajfel, 1978, p. 63). Individuals' motivations for social identification include, for example, self esteem enhancement, uncertainty reduction, and a desire to be both the same as and different from others (e.g., Brewer, 1991). When the focus of identification is the work team as a social entity to which an individual is assigned, we refer to this process as team identification (van Knippenberg \& Ellemers, 2003).

As individuals are usually members of various social groups (e.g., based on team membership, nationality, or gender), they can have multiple foci of identification and thus a range of potential social identities (Riketta \& van Dick, 2005). These can be overlapping, inclusive, exclusive, or nested within one other (Ashforth \& Mael, 1996; Brewer \& Gardner, 1996). In a given situation, individuals invoke that social identity which they perceive to fit the situational context best (i.e., it becomes "salient"); an individual's multiple identities can be ranked in a "salience hierarchy" according to their relative salience (Ashforth \& Johnson, 2001; Hogg \& Terry, 2000). Several situational cues have been argued to make team membership the salient social category for individuals' self concepts, for instance perceived team status (Chattopadhyay et al., 2004), levels of communication and interaction (Postmes et al., 2005), and especially leadership (e.g., van Knippenberg et al., 2004). With regard to the latter it is argued that by tying followers' sense of self to the collective, leaders may activate team identification as the salient social category (Lord, Brown, \& Freiberg, 1999).

\footnotetext{
${ }^{1}$ Range is restricted to studies that report change in explained variance due to charismatic/transformational leadership.
} 


\subsection{Empirical research on leadership and team identification}

Extant research on the nexus of leadership and team identification has almost exclusively focused on the influence of transformational and charismatic leadership on team identification. Kark, Shamir, and Chen (2003) were able to show that transformational leadership predicts both followers' personal identification with the leader and their social identification with the team. In a similar vein, Wu, Tsui, and Kinicki (2010) found evidence that group focused transformational leadership (i.e., inspirational motivation and idealized influence) is positively related to team identification. Walumbwa, Avolio, and Zhu (2008) confirmed a positive relationship between transformational leadership and members' team identification, just as Cregan, Bartram, and Stanton (2009). Lastly, Kearney and Gebert (2009) showed that the moderating effect of transformational leadership on the diversity outcome relationship was mediated by members' team identification.

In addition, a number of studies have investigated the effects of charismatic leadership on followers' team identification. Referring to charismatic leadership theories, Joshi, Lazarova, and Liao (2009) confirmed the positive influence of "inspirational leadership" (i.e., behaviors emphasizing a team's mission, shared values, and ideology) on members' commitment to the team (defined as team identification; Joshi et al., 2009, p. 242). Conger, Kanungo, and Menon (2000) found charismatic leadership to be positively related to team members' "sense of a collective identity" (Conger et al., 2000, p. 752). In a similar vein, Shamir et al. $(1998,2000)$ have shown charismatic leadership to be positively related to social identification in military units, thereby focusing on the charismatic leadership behaviors of emphasizing ideology, collective identity, and exemplary behaviors. According to De Cremer and van Knippenberg (2002), leaders' charisma positively influenced team members' feeling of belonging to the group. Paul, Costley, Howell, Dorfman, and Trafimow (2001) showed charismatic and integrative leadership (i.e., charisma and individualized consideration) to increase the accessibility of followers' collective self concepts.

In contrast to the works cited above, Sivunen (2006) inductively explored leadership behaviors relevant for team identification. Conducting qualitative interviews with leaders of four virtual teams, she was able to derive four different leadership tactics for strengthening team identification: "catering for the individual", "giving positive feedback", "bringing out common goals and workings", as well as "talking up team activities and face to face meetings". This study thus provides initial evidence that other leadership behaviors than charismatic or transformational leadership may be relevant for fostering followers' team identification; however, it has not adopted the perspective of those becoming identified (i.e., the followers) but the view of those who are considered to cause identification (i.e., the leaders). Moreover, research indicates that identity formation in virtual teams may be different from teams in more traditional settings (Fiol \& O'Connor, 2005). For example, due to the absence of face to face interaction, members of virtual teams have fewer cues about their team colleagues. Hence, there is more uncertainty concerning the validation of perceptions, feelings, and behaviors with other team members in virtual teams, thereby making the formation of a common identity (and the development of members' sense of belonging to the team) more difficult (Webster \& Wong, 2008). Thus, the generalizability of Sivunen's (2006) findings to traditional (face to face) teams may be questionable due to the study's setting.

To sum up, empirical research on the nexus of leadership and team identification reveals mainly two particularities. First, previous studies have neglected the followers' perspective on the role of leadership for team identification. That is, with the exception of Sivunen (2006), these studies have exclusively tested the effectiveness of predefined leadership styles (i.e., charismatic and transformational leadership) for promoting followers' team identification. From a theoretical point of view, however, identification constitutes a highly subjective process on the part of the individuals who develop identification (Kreiner \& Ashforth, 2004; Pratt, 1998). Thus, taking on the perspective of those becoming identified (i.e., the followers) seems to be indispensable for discovering leadership behaviors conducive to team identification (van Knippenberg et al., 2004). Accordingly, extant research on leadership and team identification calls for greater attention to the followers' perspective; Sivunen (2006, p. 364) for example states that "it would be important to study also the team members' point of view with respect to [leadership and] identification" (for a similar conclusion see van Knippenberg et al.'s (2004) review on leadership and team identification). Second, existing research has provided only moderate support for the effectiveness of charismatic and transformational leadership in fostering team identification, with an amount of explained variance in team identification ranging from 6 (e.g., Walumbwa et al., 2008) to 16\% (Kearney \& Gebert, 2009). Hence, taking on the followers' perspective may add to further broaden the range of leadership behaviors conducive to team identification.

Accordingly, the goal of our analysis is to explore the followers' point of view and to investigate which leadership behaviors (pertaining to team internal, formally assigned leaders; Morgeson et al., 2010) are perceived to be relevant from their perspective. For this purpose, we adopt a qualitative research approach in order to gain in depth insights into the followers' viewpoint (De Vaus, 2001).

\section{Methods and data}

\subsection{Research design}

Data was gathered in the context of a larger research project investigating the development of members' team identification. Given the poor state of knowledge on the underlying processes of team identification, a qualitative research design seemed to be the most appropriate choice of design for the larger research project (De Vaus, 2001; King, Keohane, \& Verba, 1994). Thus, an exploratory approach guided by the principles of grounded theory (Corbin \& Strauss, 2008; Glaser \& Strauss, 1967) was chosen in order to gain in depth insights into the processes and contingencies of team identification.

It was this exploratory approach that enabled us to delve into the topic of leadership: In the course of our fieldwork and interviews, we soon realized how important the role of leadership was perceived to be for the development of members' team 
identification. For example, when discussing the relation to their team, members frequently highlighted that the leaders' commitment and dedication had a great impact on their feeling of belonging. Hence, we started to put more specific questions about the leaders' behaviors and asked respondents to describe situations in which leaders had demonstrated these behaviors. Often we were then able to deduct further leadership behaviors for these situations that seemed conducive for members' identification with their team.

In such situations, we thus took advantage of the so called theoretical sampling technique which is crucial to the grounded theory approach and reflects the notion that data gathering is based on evolving concepts. That is, a researcher is encouraged to further explore those concepts and phenomena that surface during interviews and capture his particular attention by including new questions and adapting interview techniques accordingly (Corbin \& Strauss, 2008). Hence we developed an independent path of investigation within the larger research project, exclusively focused on the role of leadership for members' team identification. Thereby it was a conscious decision to stick to the qualitative research approach guided by the principles of grounded theory also in the context of the leadership analysis. It enabled us to explore the nexus of leadership and team identification more broadly and without conceptual limitations, thus promising the uncovering of previously unattended phenomena (for a similar approach, see e.g. Dutton \& Dukerich, 1991; Pratt, Rockmann, \& Kaufmann, 2006).

\subsection{Research setting and case selection}

\subsubsection{Research setting}

Our subjects of analysis were members of inter organizationally staffed teams within the system of UN peacebuilding operations. ${ }^{2}$ Peacebuilding operations are best described as networks of UN organizations tasked with the provision of security in post conflict countries, the reconstruction of public administration, and the development of civil society. They usually consist of an armed UN peacekeeping force mandated by the UN Security Council ("the mission") and a wide array of other UN organizations with presence in the country of operation. These may include UN agencies (e.g., UNHCR, WHO, ILO), funds (e.g., UNICEF, UNFPA, UNIFEM), programs (e.g., UNDP, WFP, UNAIDS), and secretariat departments (e.g., OCHA, OHCHR, DPA). ${ }^{3}$ Despite that all these UN organizations have their own leadership, mandates, personnel, and organizational cultures, they are obligated to work together under the umbrella of the peacebuilding network in order to ensure strategic and operational alignment of the entire UN family in the country of operation.

As part of every peacebuilding operation, the UN has set up several functionally cross cutting "peacebuilding teams" that plan and implement collaborative activities on behalf of the entire UN system with respect to a specific aspect of the broader UN peacebuilding agenda (e.g., disarmament, installation of a judicial system, combat of HIV/AIDS). These teams are staffed with representatives of all UN organizations that have a stake in the respective topic. Team size usually ranges between five and 12 individuals who are generally experts in the team's topic, working on a part time basis (10 25\% of their working time) in the respective team. The teams are led by so called facilitators who hold responsibility for coordinating the teams' work, spearheading team initiatives, and representing the team in senior UN decision making bodies. They are thus formally assigned leaders that are (internal) members of their respective teams (Morgeson et al., 2010).

With respect to the role of these facilitators, two aspects are noteworthy. First, the denomination of the team leaders as "facilitators" in the official UN language is semantically misleading. In fact, an exclusively technical and administrative organization of teamwork (as implied by the term "facilitator") would not be sufficient for effectively leading the peacebuilding teams. In particular, the setting in which the peacebuilding teams operate (e.g., high public pressure, risky and uncertain environments) requires leaders who not only fulfill administrative tasks, but also provide the team with guidance and motivate team members for common goal achievement. Against this background, the facilitators of the teams in our sample can be characterized as leaders in the sense of pertinent literature (e.g., Yukl, 2010). Second, due to the exceptional setting and objectives of peacebuilding teams, the leaders of our teams are faced with extraordinary leadership challenges concerning team identification. In particular, they act as integrative figures that have to unite and convey a collective team identity to members that all have their individual mandates, ideological perspectives, and are influenced by the organizational culture of their respective home organizations all of these being at times far apart (e.g., military command and control vs. democratic and participatory development aid).

\subsubsection{Case selection}

Based on preliminary expert interviews ${ }^{4}$, in a first step we chose two UN peacebuilding operations from the 16 that were operated by the UN system as main cases. Guiding principles for our choice were to limit external and contextual influences on

\footnotetext{
${ }^{2}$ For the larger research project, we used a wider set of data also including interviews with team-external subject matter experts in the countries of operation, senior UN leaders at UN headquarters in New York City and Geneva, as well as a structured document analysis.

${ }^{3}$ UN High Commissioner for Refugees (UNHCR), Word Health Organization (WHO), International Labor Organization (ILO), Food and Agriculture Organization of the UN (FAO), UN Fund for Children (UNICEF), UN Population Fund (UNFPA), UN Fund for Women (UNIFEM), UN Development Program (UNDP), World Food Program (WFP), UN Joint Program on Aids (UNAIDS), UN Office for the Coordination of Humanitarian affairs (OCHA), UN Office of the High Commissioner for Human Rights (OHCHR), UN Department for Political affairs (DPA). For a complete list of all UN organizations involved in UN peacebuilding and development operations, see http://www.undg.org/index.cfm?P=13.

${ }^{4}$ These interviews with scholars and high-ranking UN officials were conducted during the international conference "Administrative Science Meets Peacekeeping" held at the University of Konstanz (Germany) in June 2007. Furthermore, we interviewed subject matter experts at UN organizations' headquarters in Geneva and New York.
} 
the teams and their members while maximizing the differences between cases with respect to perceived collaboration success among the actors from the different UN organizations (Pettigrew, 1990). Therefore, we chose the UN peacebuilding operations in Liberia (Africa) and Haiti (the Caribbean). Both operations are "Integrated Missions", i.e., the formal set up and organizational structures in both cases follow the same guidelines as provided by the UN's Department for Peacekeeping Operations. However, most experts as well as available literature indicated that the Liberian peacebuilding operation represented one of the UN's most advanced operations in terms of UN inter organizational collaboration, whereas in the Haitian UN family collaboration problems were widespread (Frerks, Klem, Laar, \& Klingeren, 2006).

Thus already the choice of the two main cases of investigation (i.e., the peacebuilding operations in which the later selected teams and their members were situated) proved to be appropriate for studying the influence of leadership on members' team identification: It can be assumed that the overall collaboration success and atmosphere in a particular peacebuilding operation also reflect on the atmosphere of its sub units (i.e. the peacebuilding teams) and that the process (as well as the likeliness) of members' identification with their team is also affected by this environment (for the link between the performance of a social entity and members' identification, also see the next section on within case selection). Hence, the team leaders in the two different peacebuilding operations may face quite different circumstances and challenges in the course of fostering members' team identification, thereby adding to the variance of observable leadership behaviors in our sample.

\subsubsection{Within case selection}

In a second step, we chose seven teams from the two peacebuilding operations as our main units of analysis. According to the concept of most different within case design, we sampled the teams on the outcome variable of perceived group functioning, trying to include well working as well as poor working teams. This approach was adopted since it further added to the potential variance of observable leadership behaviors relevant for team identification: It has been argued that identification is more likely in successful than in unsuccessful organizational entities (Mael \& Ashforth, 1992; Tajfel \& Turner, 1986). ${ }^{5}$ Thus, given the high variance of our cases with regard to group functioning, we are confident that we were able to capture the widest possible array of leadership behaviors that hold relevance for the emergence of members' team identification. Yet, in order to limit contextual variance in terms of the teams' topics, we aimed at investigating the same topical domain in both countries. As a result, we selected three teams in Liberia and three teams in Haiti with matching domain pairs (UN Communication Groups; UN Gender Theme Groups; Joint UN Teams on HIV/AIDS). ${ }^{6}$ In addition, we chose one team in Liberia commissioned with the build up of regional governance capacity in a rural district to capture leadership behaviors in a particularly extreme setting this team was frequently subject to security threats and operated under very adverse living conditions "in the bush". ${ }^{7}$ Table 1 provides an overview of the seven teams in terms of team performance, team domain, and team member diversity.

We believe that the choice of these teams and their members constituted an appropriate setting for investigating the role of leadership on team identification since it enabled us to increase the variance of observable leadership behaviors and their impact on followers' team identification. This is mainly due to three reasons: First, by choosing both successful and unsuccessful teams, we were able to gain insights into leadership behaviors relevant for the development of team identification in favorable and less favorable circumstances. As outlined above, research has shown that members are generally more inclined to identify with social categories that are able to enhance their self esteem (Mael \& Ashforth, 1992; Tajfel \& Turner, 1986). Accordingly, it is probable that different types of leadership behaviors aimed at fostering members' team identification are required and, thus, likely to occur in successful and unsuccessful teams.

Second, the setting of peacebuilding teams allows for eliciting leadership behaviors and their impact on team identification in a wide range of topical contexts and situations. The teams' topics ranged from a classical field such as communication over the idealism swayed topic of gender to the security focused issue of disarmament. Furthermore, the situations in which the teams operated ranged from standard administrative tasks in day to day meeting routine to time critical interventions in life threatening security situations. Such a large variety of member activities and situations is barely found in other settings and thereby makes it likely to capture a broad spectrum of leadership behaviors relevant for members' team identification.

\footnotetext{
${ }^{5}$ Information about the performance of the different teams was elicited in previous interviews with team-external actors (such as other UN officials or local UN organization heads). These interviews furthermore helped us to gain insights into the teams' histories. Once the field research had started, we were able to collect additional quantitative data on team performance in some of the teams (all members in five out of seven teams; scale by Oh et al., 2004) and on team identification (all members from all teams; scale by Edwards \& Peccei, 2007). The correlation between team performance and the average degree of team identification is $.92(\mathrm{p}<.05)$ for the five teams, thereby justifying our sampling approach ex-post.

${ }^{6}$ The UN Communication Groups bring together communication officers from all major UN players to coordinate and devise external communication and public relations as well as to support national efforts to build up a local media landscape. The UN Gender Theme Groups consist of the UN organizations' gender focal points and are tasked with devising gender policy advice to the national government. The Joint UN Teams on HIV/AIDS are set up to formulate and implement a coherent UN strategy with respect to the epidemic and support activities of the local government in this domain.

${ }^{7}$ Originally, we had envisioned to conduct our analysis in eight teams, four matching pairs from each country. Yet, since in the Haitian peacebuilding operation the equivalent to the Liberian Team $\mathrm{D}$ (the team in charge of operations coordination in a rural outpost) was only poorly developed, we were not able to complete proper interviews with all members. Therefore the number of investigated teams was also the result of pragmatic decisions. Nevertheless, given the highly turbulent and outright dangerous setting of UN peacebuilding operations as well as the extremely complicated access for researchers, we are convinced that the fact that we were able to interview all members of the seven teams constitutes a very good result in terms of data quality.
} 
Table 1

Team characteristics and member diversity in Teams A-G.

\begin{tabular}{|c|c|c|c|c|c|c|c|}
\hline Team & A & B & C & D & $\mathrm{E}$ & F & G \\
\hline \multicolumn{8}{|l|}{ Team characteristics } \\
\hline Country of operation & Liberia & Liberia & Liberia & Liberia & Haiti & Haiti & Haiti \\
\hline Team domain & Communication/PR & HIV/AIDS policy & Gender policy & Local governance. & HIV/AIDS policy & Communication/PR & Gender policy \\
\hline Team performance ${ }^{a}$ & High & Low & High & High & Medium & Low & Medium \\
\hline \multicolumn{8}{|l|}{ Team member diversity } \\
\hline Age groups ${ }^{b}$ & 3 & 4 & 4 & 2 & 3 & 3 & 4 \\
\hline Gender (male/female) & $10 / 0$ & $6 / 4$ & $5 / 4$ & $9 / 3$ & $2 / 7$ & $3 / 5$ & $0 / 5$ \\
\hline Ethnic groups ${ }^{c}$ & 3 & 3 & 2 & 4 & 4 & 4 & 5 \\
\hline Nationalities & 6 & 5 & 7 & 7 & 7 & 4 & 5 \\
\hline Educational fields ${ }^{d}$ & 4 & 4 & 3 & 5 & 5 & 4 & 3 \\
\hline Organizations & 9 & 9 & 7 & 8 & 8 & 8 & 4 \\
\hline $\begin{array}{l}\text { Mean member tenure } \\
\text { (months) }\end{array}$ & 17.7 & 15.5 & 21.7 & 19.3 & 17.9 & 20.3 & 13.0 \\
\hline Tenure range (months) & $5-31$ & $5-23$ & $6-48$ & $4-52$ & $2-24$ & $2-30$ & $13-13$ \\
\hline
\end{tabular}

a Information about the performance of the different teams was elicited in preliminary interviews with team external actors (such as other UN officials or local UN organization heads). In addition, we administered a survey among members of the teams in which they indicated their perception about their team's performance (based on the scale by Oh, Chung, \& Labianca, 2004).

b We distinguish four age groups: $21-30$ (group 1); 31-40 (group 2); 41-50 (group 3): 51-60 (group 4).

- Building on the categorization of Joshi and Roh (2009), we differentiate between the following five ethnicities: White, Black, Hispanic, Asian, and Other (e.g, Caribbean, Arabic etc.).

d We differentiate between the following five fields of education: Engineering, Medicine, Humanities, Natural Science, and Business Administration. This classification corresponds with the departmental structure of most universities, as well as the categories used by the United Nations Human Resource Office.

Third, the members of the peacebuilding teams were very diverse with regard to several attributes (e.g., age, gender, ethnicity, educational background; see Table 1). By investigating such extreme cases with regard to member diversity, we expected to capture the entire spectrum of different follower perspectives on the role of leadership for team identification (Eisenhardt, 1989; Yin, 2003). Thereby, we were able to avoid cultural or occupational bias that usually comes with research in more conventional settings (i.e., male dominated private sector firms in Western countries). This fact appears to be even more important given that for every leader we received assessments from all subordinates, thus exhibiting a very broad set of perspectives on his or her respective leadership behaviors.

\subsection{Data collection and data analysis}

\subsubsection{Data collection}

Data was gathered on two multi week field trips to the selected UN operations (October/November 2008 to Liberia, March/ April 2009 to Haiti). During these visits, we conducted 63 face to face interviews with all members of the seven selected teams. All interviews were audio recorded and transcribed verbatim. The interviews lasted between 30 and 120 min with an average of approximately $60 \mathrm{~min}$ and were mostly conducted by two researchers.

The interviews followed a semi structured yet flexible form to allow sufficient freedom to explore issues and topics that respondents deemed particularly relevant for their feeling of belonging to the team (Patton, 1990; Rubin \& Rubin, 2005). Thereby, we made sure that the respondents were not directly confronted with the terms "identification" or "leadership" at the outset of the interviews in order to avoid possible response bias and encourage the mentioning of a wide array of topics and concepts in the answers of our interviewees (Kvale, 1996; Leech, 2002; Rubin \& Rubin, 2005; Spradley, 1979). Instead, we started our conversation with asking more generally about members' feeling of belonging and attachment to their team and potential influence factors on this feeling. This had the effect that the (culturally very diverse) interviewees were not thrown off by a possible misinterpretation of semantics and approached the topic with a maximum of openness and a minimum of possible conceptual predetermination. Yet, in order to ensure that our respondents grasped team identification as the topic of the interview unambiguously and all in a similar manner, we presented a chart with seven converging pairs of circles as a visual aid at the beginning of every interview. This chart was adapted for our purposes from previous research in the context of organizational and team identification (Bergami \& Bagozzi, 2000; Rockmann, Pratt, \& Northcraft, 2007). One circle in each pair was marked with "You" and one with "Your Team". The circles overlapped to different degrees and while showing them to the respondents, we made clear that our interview aimed at exploring how much overlap there was between them and their team and which factors they believed determined their degree of "belongingness" to the team.

With our interview approach, we made sure on the one hand that our interview partners were fully aware of the major subject of our conversation throughout the entire interview process; on the other hand, it allowed us to maintain the exploratory openness inherent to our research design. It was interesting to observe that during the course of the interviews, almost all respondents addressed the topic of leadership without having been asked about it. Once the topic had been raised, we then followed up with more specific questions, such as "What did the leader exactly do that caused you to feel greater belonging to the 
team?", "How did the leader react when you distanced yourself from the team?", "How did changes in the team's leadership affect your bond to the collective?", "Through which leadership related measures/behaviors did your feeling of belonging to the team improve or deteriorate?". Consider the following interview episode as an example for our interview approach:

Interviewer: What led to your altered perception of belonging?

Respondent: The change of leadership, [leader's name] actually initiated most of the changes.

Interviewer: How did she do that?

Respondent: Well, through internal discussions (...) working towards defining the kind of place of the group.

In addition to conducting interviews, we attended several team meetings in which we were able to get a first hand impression of the tasks and topics in the teams of our sample. We captured these participatory observations with detailed meeting protocols which helped us to better understand the subject matters that our interviewees referred to during the interviews.

\subsubsection{Data analysis}

For data analysis, we used an iterative coding technique based on the principles formulated by Strauss and Corbin (1990) and Miles and Huberman (1994). This approach has been employed throughout many works of qualitative research, like Dutton and Dukerich's (1991) observations of organizational identity of the Port Authority of New York and New Jersey, Elsbach and Kramer's (1996) study on members' interpretations of business school rankings, and Pratt's seminal works on identification of Amway distributors (Pratt, 2000) as well as medical professionals (Pratt et al., 2006). Accordingly, our data analysis was conducted in two stages: First, an exploratory data analysis on site in Liberia and Haiti and second a computer assisted analysis off site with the help of the qualitative data analysis software Atlas.ti.

During the first phase of on site analysis in the countries of operation, we followed the recommendations of pertinent literature and started the analysis immediately after the first team member interview (e.g., Eisenhardt, 1989). Our approach to this part of the analysis is perhaps best described as "structured discussions": In essence, after an interview was over, we talked about what we had heard in the interview, discussed interesting statements and instances with respect to leadership behaviors and compared them with handwritten notes and memos of particular incidents. If necessary, we went back to certain passages in the interviews and consulted the audio records. As a result of the post interview exchange (i.e., "open coding"), we produced an initial list of descriptive categories and interpretative codes as well as concepts. At this stage of the research project, however, we did not use this list as a codebook for analyzing interview transcripts (only a few interviews had been transcribed at this point); instead it served as an instrument for guiding our subsequent interviews. The list was thus intended to ensure that all leadership related aspects that had surfaced in the completed interviews were explored more deeply. In this process of simultaneous data analysis and collection, we continuously adapted the concepts and categories in our provisionary list of leadership behaviors and modified our interview guideline several times to reflect emerging topics. As a consequence, the data that we gathered in the field was extremely wide in respect to the range of potential leadership behaviors and thus provided an ideal basis for structuring and categorizing leadership behaviors during the second phase of analysis.

In the second phase, the interview transcripts were analyzed using the qualitative data analysis software Atlas.ti. We started with two researchers independently identifying statements regarding our informants' experiences of leadership and team identification via open coding in several interviews (Locke, 2001). Thereby, the provisionary list of categories and concepts that had emerged from our on site analysis served as a point of departure for the coding process. While categorizing the leadership behaviors, we always took the context of the quotes into consideration; that is, when deriving the inductive categories, we examined the quotations always in relation to the specific situations and incidents in which the leadership behaviors had occurred. As the analysis proceeded, we iteratively refined and extended the coding scheme to capture additional categories and their dimensions (open coding). After several rounds of coding and re coding, redundant sub codes were eliminated. Some codes were merged, and a generic common meaning was assigned to each code. Subsequently, we started with axial coding, i.e., the process of relating concepts and categories with one another by inductively and deductively combining them.

For example, we captured the various incidents of leader behaviors reflecting strategic sensemaking and the clarification of team goals as the "clarifying team goals" construct. In order to develop a coherent picture of the surfacing leadership behaviors, we then reflected on the relations between the different leadership behaviors and considered alternative models of categorization. Once we had developed a preliminary list of behaviors, we again carefully examined its fit with the data (Glaser \& Strauss, 1967; Locke, 2001). During the process of interview analysis, it proved very useful to consult our observation protocols from the team meetings which helped us to put some of the quotes which referred to special instances, tasks, and topics of the teams into the context of the teams' subject matters. Fig. 1 provides an example of our data structure using the aggregate leadership dimension "providing guidance".

At the end of our analysis, the themes, instances, and behaviors that were inductively gathered during the interviews were condensed into a two layered data structure. On the first level, we derived nine different leadership behaviors that members perceived to promote their identification with the team. Subsequently, we searched for underlying patterns in the data in order to further integrate, systematize, and categorize the findings. As a result, the nine leadership behaviors were summarized on the second level into four aggregate leadership dimensions (see Fig. 2): "providing guidance", "encouraging involvement", "role modeling", and "facilitating teamwork". 


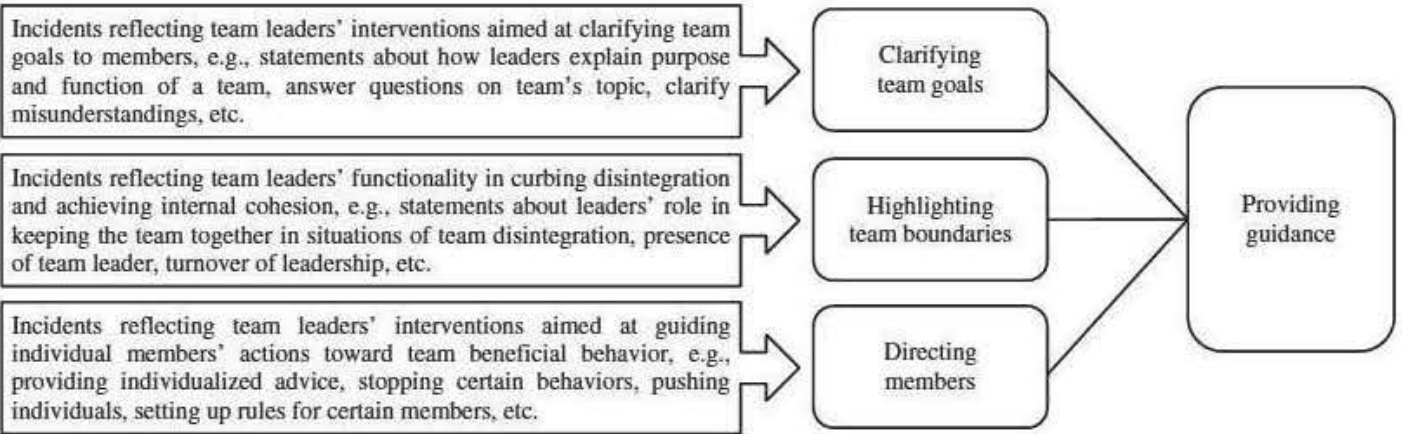

Fig. 1. Exemplary data structure: Providing guidance.

\section{Results}

In the following, the four aggregate leadership dimensions and their corresponding leadership behaviors will be presented in detail. For each leadership behavior, we start with a short summary before describing an exemplary situation in one of the teams of our sample; these descriptions are, as all data we use in this paper, also based on the narratives of our interviewees. Moreover, throughout the text, we provide some exemplary quotes from our interviews reflecting instances of leadership behaviors that our respondents perceived to contribute to their sense of belonging, attachment, and commitment to the team (also see Appendix A for more examples from our data).

\subsection{Providing guidance}

This aggregate leadership dimension comprises leadership behaviors relating to the provision of direction and advice to team members, thus reflecting rather directive, top down interventions on the part of the leader. Three different leadership behaviors surfaced from our data which can be subsumed under this aggregate dimension and which can be considered to represent different aspects of "providing guidance", that is, in a strategic (i.e., "clarifying team goals"), structural (i.e., "highlighting team boundaries"), and behavioral sense (i.e., "directing members").

\subsubsection{Clarifying team goals}

This leadership behavior encompasses individuals' perceptions of leader interventions aimed at providing strategic sensemaking to team members in order to clarify the agenda and the goals of a team.

Several leaders in our sample engaged in actions that aimed at both determining and clarifying the agenda and the goals that a team had to pursue. During our interviews, it became apparent that a number of respondents perceived this leadership behavior

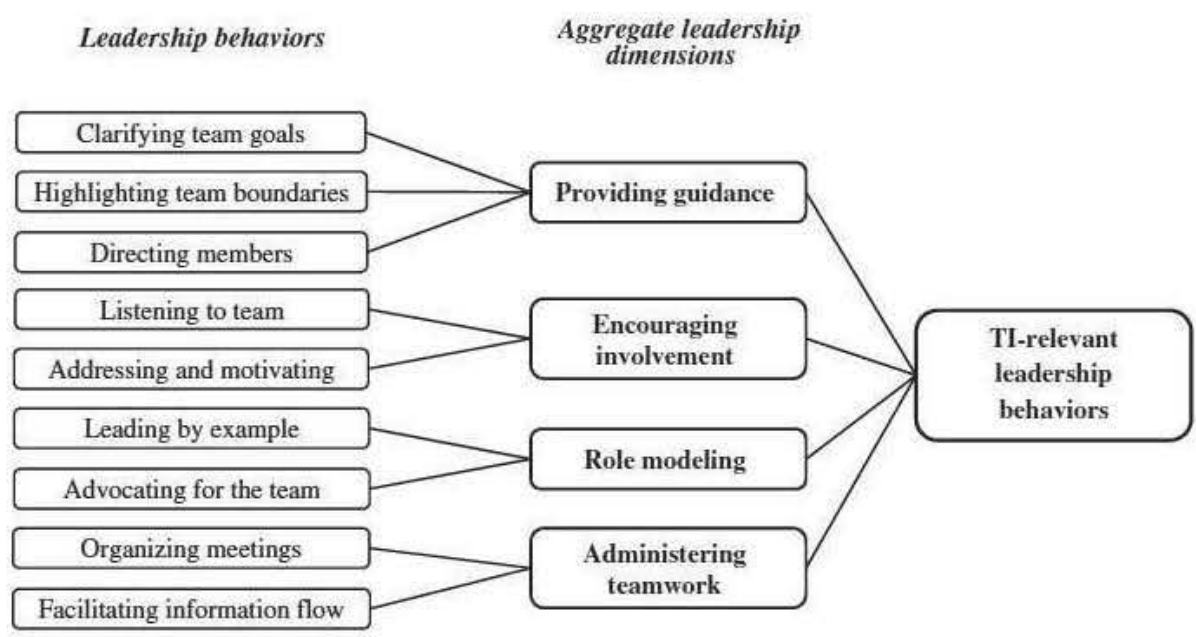

Fig. 2. Overview of leadership behaviors and aggregate leadership dimensions relevant for team identification (TI). 
as a trigger for their commitment to the team. For instance in Team $C$, the leader organized a small survey about the topic, meaning, and problems in the team. On this basis she was able to see which questions members had and where they were still lacking understanding of the team's topic and appreciation of the other agencies. According to our interviewees in Team C, in personal conversations the leader then sought to clarify misunderstandings of individual members and explain the sense of working together in the team. By clarifying the goals and function of the team as a whole, leaders also helped members to elicit their own role in the team and thereby develop a deeper appreciation of the team. As a response to the question what had strengthened her attachment to the team, one member of Team $C$ recalled:

"I remember that [the leader] helped us get a better idea of the process and explained the different structures of the organization in terms of the relationship between [the team] and the agencies and the work they are doing, the funding mechanism. And also the implementation strategy, all these things, just to bring us into the process, to make us become familiar with what we are doing. So I began to see a sense in [the team]." (R91)

Also in Team E, evidence for such clarifying behaviors could be found as the following quote illustrates:

"Something as simple as someone taking the time to really summarize, understanding the whole, ... all the paperwork and then summarizing into a reasonable, legible understanding level of professionals ... And then saying ok, this is where we fit and this is how we are interlinked. The [leader] finally was the one who put it all into a very nice understanding format." (R133)

When being asked about why he perceives leadership to be important for his commitment to the team, a respondent from another team stated:

"Not having the clarity of vision, the clarity of process in terms of what role does the team play a lot of these issues are being resolved with the presence of the leader." (R122)

From a theoretical point of view, leaders' strategic sensemaking may contribute to the clarity of the common social identity in a team (Chattopadhyay et al., 2004) which, in turn, promotes members' team identification (Ashforth et al., 2008). By clarifying the team's goals, leaders advance team members' understanding of their team's purpose and function within the broader context of the UN peacebuilding operation. Thus, leaders contribute to team members' understanding of "who are we as a team" (i.e., the common social identity) which serves as a basis for the formation of individual members' team identification (Ashforth et al., 2008; Chattopadhyay et al., 2004).

\subsubsection{Highlighting team boundaries}

This leadership behavior comprises incidents from our interviews that reflect a leader's capacity to achieve internal coherence and cohesion and to curb disintegration of the team.

A situation in Team D illustrates how the leader may contribute to highlighting a team's boundaries with the use of symbols: Despite the fact that all organizations in a UN peace operation belong to the UN family, in many teams two fractions are observable humanitarian actors on the one side and political/military actors on the other. This separation is also represented in the design of the vehicles that are used by the organizations. While the humanitarian agencies have white cars with blue UN letters on the side, the political and military oriented organizations use white with black UN letters. The same also applies to representatives' business cards: Organizations like UNHCR use blue letters, organizations like UNPOL black letters. This division has already found its way into UN slang: Team members often refer to the "blue" and the "black" UN when speaking about the different organizations. According to our interviewees from Team D, in order to break up the division, the team leader decided that the business cards of members should all use the same black lettering and a consistent wording to mark that all members belong to this particular team and to distinguish it from other teams. While talking about leader interventions that he perceived to have strengthened his commitment to the team, a respondent from Team D said:

"[Because of the leader], we now don't have the black and blue thing here.... The projects are all in collaboration with other UN agencies. And we just have to work together. There is no way we can make any decision without the other one involved." (R110)

Viewed through the lens of social identity theory, by highlighting a team's boundaries, leaders may contribute to members' in and out group categorizations vis à vis other teams and external actors of the UN mission; thereby, they may foster the perception of the team as an in group and strengthen the feeling of belonging to the team (Tajfel \& Turner, 1986). In addition, "highlighting team boundaries" did not only involve manifest behavioral interventions. Instead, often the mere perception of "having a leader" or, as one respondent termed it, "a parent to the group" (R43) sufficed members to define the boundaries of the team. Hence, "highlighting team boundaries" relates to the provision of structural guidance for the team, with the leader serving as an integrative figure. The leader provides team members with the possibility of differentiation vis à vis external actors and 
serves as a starting point for the development of team identification. Consider the following quote from our interview with a team member:

Interviewer: "Would you say that among the agencies there has developed something like a shared feeling of belonging? As really seen, not only speaking of one UN but also feeling a belonging to the [team] as 'One UN' instead of being [your home organization]."

Respondent: "Yes. I think the very fact that [leader's name] is the chairman and nobody actually questioning that chairmanship. And it is not the question why is UNHCR chairing the meeting. Why not UNDP or WFP. Because everybody understands that he is the senior member and he's the chair. But he is not looked at as the UNHCR representative. Everybody knows that he works for UNHCR but in the meetings he is not the representative of UNHCR, he is the team, the chairman of the team." (R77)

Yet, the integrative role of the leader often only became obvious when he or she had left as the following quote from Team $\mathrm{F}$ shows:

"I mean if he [the leader] leaves, the whole thing will disintegrate so I really hope he stays until somebody else comes." (R140)

\subsubsection{Directing members}

This leadership behavior refers to interviewees' descriptions of leader interventions aimed at promoting members' team oriented behaviors.

For example in Team A, for most of the time of its existence, attendance of team members was unstable. According to the members, the main reason for this was the low reputation of the team among senior UN leadership and, as a consequence, a lax attitude towards participation of their agencies' staff. Shortly after his arrival, the new head took a number of measures to instill a new sense of appreciation for the team within the UN community and thereby was also able to increase participation. For example, he instructed members to hold their meetings on a rotational basis in changing agency offices. For each of these meetings, he asked the member of the hosting organization to prepare the agenda and invite the representative of the hosting UN organization to open the meeting. As one member of Team A reported:

"[The leader] started to hold meetings on rotational basis, putting more responsibility into the arms of individual members, motivating them and giving them visibility in their agency." (R112)

In this way the leader succeeded in making the team become more visible within the UN community and it was increasingly positively viewed by each of its members. Put differently, it became something special to be a member of the team and the members increasingly took pride in their belonging to the team.

Two explanations appear to be plausible with regard to how the articulation of expectations concerning team oriented behaviors may foster members' team identification. On the one hand, promoting team oriented behaviors may benefit team effectiveness. This, in turn, may instill team members' feeling of attachment and belonging to the team (Tajfel \& Turner, 1986; van Knippenberg \& Hogg, 2003). On the other hand, it appears to be possible that by articulating concise expectations with regard to team oriented behaviors, leaders increase the understanding among team members about their role in the team. This clarity about one's role can be a vital precondition for a sense of belonging to and identification with a team (Pratt et al., 2006). In contrast to strategic agenda setting and the structural guidance of defining a team's boundaries, "directing members" relates to guidance concerning team members' behavioral conduct. This comprises top down, sometimes even authoritarian leadership behaviors. The following statement from a team member asked about which leadership behavior in his opinion is essential for the development of a common sense of belonging to the team illustrates this line of reasoning:

"[It only works] if you have clear leadership and a leader that clearly defines what job he wants to be done and by whom." (R19)

\subsection{Encouraging involvement}

The second aggregate leadership dimension encompasses leadership behaviors pertaining to the motivation of team members for engaging in bottom up participation and proactive behaviors for the benefit of the collective. By showing good listening skills and giving team members the opportunity to take part in team activities, discussions, and decisions, leaders were able to foster identification with the team. According to the picture that emerged from our data, two leadership behaviors can be differentiated within this aggregate leadership dimension.

\subsubsection{Listening to team}

"Listening to team" reflects team leaders' listening to members' ideas, thoughts, and concerns and actively taking up suggestions emerging from the team. As it surfaced during our interviews, this also refers to the leader being sensitive with regard to more informal kinds of communication and more indirect or subtle hints voiced by team members. 
A situation that we heard about during our interviews in one of the teams in our Liberian sample illustrates the importance of leaders' good listening skills: In Team A, the leader came up with the initiative to meet once a week over lunch in one of the few operational hotels of Liberia's capital, Monrovia; these meetings were intended to provide room for discussing team issues in a rather informal atmosphere. However, after several weeks it became apparent that a couple of members did not show up at every lunch meeting. As a consequence, the leader proactively engaged with the team members to learn more about the reasons for their absence. He received the feedback that some of the local members of the team felt that dining in the hotel was quite pricy and that they could not afford it on a regular basis. In addition, some members felt that it was inappropriate to meet in a luxurious environment while discussing how to rebuild the country and improve the situation of the poor Liberian population. The leader immediately reacted to this problem and canceled the lunch meetings. Instead he started to include time slots before and after the regular team meetings in order to allow members to network and exchange their ideas in a less formal setting. While referring to the role of the leader for his commitment to the team, one member of Team A remembered the situation as follows:

"I told the chair at that time who was acting chief before [the current leader] came, I don't think that meeting over lunch was appropriate. Because some local staff who were representing these agencies at the meetings because of the lunch issue some of them were not coming to meeting. So he agreed with me and we scraped that of. And it is because of that that a lot of people come to the meeting now." (R141)

In our interviews, we frequently noticed how important it was perceived for members' feeling of belonging to the team that leaders showed good listening skills with regard to members' ideas and input. This finding resonates with previous research that has illustrated the importance of bottom up communication in teams for the formation of a common social identity (Postmes et al., 2005). Hence, leadership behavior aimed at taking up team members' points of view is considered to be instrumental by the team members to express their ideas and feelings concerning the question "who are we as a team". The formation of a shared social identity, in turn, serves as a basis for the development of team identification for the individual team members (Ashforth et al., 2008).

\subsubsection{Addressing and motivating team}

This leadership behavior goes beyond the mere listening or taking up suggestions from team members and pertains to leaders' proactive encouragement of team members' involvement in the team.

A situation from Team E which several of our respondents referred to might serve as a good illustration for this leadership behavior. The team, which was responsible for fighting the HIV/AIDS pandemic in Haiti, had for most of its existence suffered from a lack of recognition within the UN community. In particular due to the disastrous living situation of the general population, other topics such as food, shelter and security were widely perceived to be more important and urgent. This became most obvious when a series of tropical storms hit the island in 2009 and flooding destroyed many cities, leaving thousands homeless and in need of immediate humanitarian support. Because the team's topic was not considered an important pillar of the UN's work in the disaster response, the team and its members were excluded from most strategic decisions taken by the UN at that time. In this situation, the leader of the team took an unusual measure which many members described as a crucial turning point in their relation to and appreciation of the team. The leader called a meeting and urged members to think about how they could help with their expertise in response to the humanitarian crisis. Among other things, one idea coming out of the team's brainstorming was the following: In the refugee camps that the UN was about to set up, there would be certainly issues such as sexually transmitted diseases as well as rape and sexual abuse and it would be important to include counter measures and awareness campaigns in the design and administration of the camps. On this basis the leader then asked the team to develop an action plan for improving the shelter management with respect to HIV/AIDS problems. Motivated by their leader, the members jointly worked out a plan and proposed a document to senior UN leadership. As a result of the convincing presentation and the lobbying of the team's leader, the plan eventually found its way into the disaster response strategy. The following quote from an interview sequence revolving around the importance of leadership for the development of commitment to the team illustrates the situation in Team E:

"When the catastrophe arrived and we go to the [the senior UN leadership], and we say ok, we are not on the humanitarian thing, but we do have to do something, and they say that the [the team] doesn't have to be there, things like that. But [the leader] encouraged us and we insisted and we did make it a part of it". (R26)

This led to two positive dynamics in the team: First, members realized that their voice indeed counted in the UN family and that their team was capable of coming up with relevant answers; second, they realized that this success would not have been possible to realize if they all had separately proposed isolated measures. According to members from Team E, this demonstrated the sense of working together as a team.

By individually addressing team members and persuading them to take part in team activities, leaders can thus succeed in both activating members for the purpose of the team and strengthening their identification with it. As Postmes et al. (2005) have pointed out, "[...] it is precisely because individuals actively engage with each other that a small group of unconnected individuals can be transformed into an entity capable of taking a collective stance and undertaking collective action" (p. 34). Thereby, according to the perceptions of the team members in our sample, leaders can facilitate and encourage team members' involvement in the team which serves as a basis for the formation of a shared social identity. These leadership behaviors include 
transporting the notion of the team's relevance, encouraging participation in meetings, and generally promoting proactive involvement by team members. The following quotes from members of Team D and F further illustrate this leadership behavior:

"So it is a process that the leader has to constantly get members onboard, keep them interested and get them going."

“Talking individually, getting encouraging them, the members of the [team], to begin to take initiatives like getting the radio producer back up and running." (R128).

\subsection{Role modeling}

The third aggregate leadership dimension relates to exemplary conduct on the part of the leaders. That is, the leadership behaviors subsumed under this dimension pertain to leaders' prototypical team oriented behaviors that were perceived to contribute to the development of team identification by our respondents. Especially in Teams A, C and E, occurrences for such role modeling behaviors were found; these leadership behaviors could be distilled into two sub aspects, depending on the sphere in which the leaders' team oriented behaviors took place (i.e., within team sphere vs. outside team sphere).

\subsubsection{Leading by example}

This leadership behavior comprises team members' accounts of leader interventions reflecting exemplary team oriented conduct vis à vis team members (within team sphere). It pertains in particular to the display of a feeling of belonging to the collective and commitment to the team's objectives.

For instance in Team E, the leader did not show exemplary conduct in the eyes of many team members. One incident that several interviewees mentioned was a situation after a topic related training workshop in Accra (Ghana) in which most team members participated. After the return from Ghana, team members somehow expected from their leader to take the initiative and review the topics of the workshop in order to summarize the main take aways and discuss the major conclusions for the team's work. However, the leader did not consider this to be part of his job because, according to his self concept, he did not regard himself to be part of the team but rather saw himself as an external chairman. This positioning led to increased dissatisfaction among team members as it set a negative example for the team. The following statement from a member of Team E illustrates the situation after the workshop:

"But he divorces himself from the [team] and says 'You are the [team].', you know, 'You should do this, you should do that.' And I was thinking that even when we came from Accra, he was looking up to us to call a meeting. But instead he as the head of the [team], even though he didn't go to Accra should have been the main one to spearhead all of our activities." (R53)

On the contrary, when team leaders showed exemplary conduct, this was perceived by team members to have a positive impact on their attachment and feeling of belonging to the team. A possible explanation for this finding is that when leaders display team oriented behavior (e.g., showing commitment to team goals), team members may infer a team oriented attitude and commitment on the part of the leader. This, in turn, may activate the collective level of their self concepts, thereby fostering their identification with the team (van Knippenberg \& Hogg, 2003). Shamir et al. (1993) were among the first to propose that leaders' role modeling influences followers' self concepts through a process by which followers adapt their beliefs, feelings, and behaviors to those of the leader (Kark et al., 2003). In Team E, one respondent illustrated the importance of leaders' exemplary conduct for his commitment to the team by stating:

"From the top down depending of the commitment and the passion the leader has, it reflects positively or negatively on the group. [The leader's] involvement ... I think the [team] probably started within his leadership." (R133)

\subsubsection{Advocating for the team}

The second leadership behavior under the "role modeling" dimension refers to leaders' interventions vis à vis team external actors aimed at achieving acceptance for team specific issues (outside team sphere). Here, team members considered it to be particularly conducive for their attachment to the team if the leader was perceived to stand up for the team and to determinedly represent it vis à vis external actors, in particular senior leadership.

When being asked on the role of leadership for their sense of belonging to the team, a number of interviewees from Team $D$ referred to an episode from the early stage of the team's existence. During the set up of Team D, there was a shortage of clean water and sanitary installations for the team members. The only delegating agency of one of the members that had sufficient supplies was the military arm of the operations that had drilled a cistern in their camp. However, due to UN regulations, the other agencies (and thus the other team members except for the military representative) were not allowed to use these resources, as they were reserved for military use only. In this situation, the leader took the initiative and lobbied in the headquarters to change the policy. When she met resistance, she set an ultimatum: Either the entire team would get access to the military facilities, or she would withdraw from the operation. This tactic worked: Not only did all team members get enough water and access to sanitary installations, but the team also grew much closer together. The following exemplary quote illustrates the leader's intervention in Team E:

"But [the leader] said 'OK, if they don't do it then we cannot be here. And then the mission has to change the rule for them to provide water to the UN staff because it is the only way...' And all the rules for the [the team] are different. Because they make the rules different because of the situation. And they showed it can happen." (R64) 
Advocating for the team vis à vis external actors thus signalizes a great sense of commitment and belonging to the team on the part of the leader which, in turn, may instill team members' feelings of loyalty to the team (Shamir et al., 1993). Moreover, from a social identity perspective, it appears to be possible that leaders' advocating for the team may fuel team members' in and out group categorizations vis à vis team external actors (Tajfel \& Turner, 1986). That is, by displaying defensive behaviors to actors outside the team, leaders may foster the perception of team external actors as an out group that may even constitute some kind of identity threat (Branscombe, Ellemers, Spears, \& Doosje, 1999). This, in turn, may strengthen the categorization of team members as an in group and, as a consequence, members' identification with their team. Explaining how leadership related to his commitment to the team, a member of Team A provided another example of a leader behavior reflecting advocating for the team:

"But now the [leader] has to ... [go to senior leadership] and it makes a difference. Because sometimes they have to devote time to go and meet the [senior leader] and to inform [him] and to sell the idea and whatever and to convince them to put some money on this activity and so it makes a difference." (R116)

\subsection{Administering teamwork}

The final aggregate leadership dimension comprises all leadership behaviors that deal with the technical and administrative organization of teamwork. Here our data prompted us to differentiate between two leadership behaviors: "organizing meetings" and "facilitating information flow".

\subsubsection{Organizing meetings}

"Organizing meetings" refers to leadership behaviors aimed at administering and planning team meetings. Among these activities, in particular the preparation of meetings, the operational coordination during meetings, and effective following up were mentioned as important elements by our respondents when referring to the importance of leadership for their sense of belonging to the team.

In Team $\mathrm{D}$ for example, the organization of the team's meetings by the leader was considered to be exemplary. Thereby, our respondents reported that the leader, for instance, prepared team meetings in a very diligent way: In advance of the meetings he personally spoke to every member to find out whether there were issues that they would like to discuss in the meeting. If the issue seemed reasonable, the leader put it on the meeting agenda which was circulated to all members in advance of the meeting. However, if a member approached the leader with an unimportant point for the agenda, the leader directly explained to the person why that issue should not be discussed in the team. This way, the leader's routine served the function that irrelevant aspects were shielded from the agenda. As a consequence of this leadership behavior, team meetings were perceived to be very efficient; this, in turn, fostered the satisfaction with and appreciation of the team, thereby constituting an important precondition for the development of identification with the team. Responding to the question why she felt committed to her team, one member of Team D for example responded:

"I think it's because of the chairperson ...You go there, you get minutes of the meetings, they take attendance, they forward emails, any information you know, because they always keep you abreast, so that you are encouraged to go to the meeting. I think that's why. It's the chair of the meeting, the coordination, the whole team they are instrumental to see that things happen." (R70)

According to self categorization theory, both the valence and clarity of a group prototype (i.e., a common social identity) are important for individuals' team identification (Chattopadhyay et al., 2004). The more positive a prototype (i.e., the higher the prototype valence is), the more likely it is that individuals incorporate this prototype into their own identity (e.g., Grieve \& Hogg, 1999; Hogg \& Hains, 1996). Thus, when teamwork is organized smoothly, members regard the team as more effective and hence as a more positive prototype, thereby leading to higher degrees of team identification.

\subsubsection{Facilitating information flow}

In addition, identification enhancing team administration also included frequent incidents of "facilitating information flow". According to our interviewees, this mainly refers to leader interventions aimed at briefing members about team relevant issues.

A good example for this leadership behavior can be found in Team $\mathrm{D}$ in which team members reported that the leader served as a channel through which information among team members is distributed. In this team, the leader for instance initiated the sharing of information about the military patrol schedule to civilian members of his team. This way, members from non armed UN agencies were always in the loop about troop movements around the provincial outpost; hence, they were either able to synchronize their own field trips and supply transports in a way that they could benefit from the increased security or in case they preferred not to be seen around heavily armed UN troops avoid the same route on that day. One senior military official in the team for example described:

“When I go to meetings and I introduce myself I say 'I am gonna be traveling there and there'. Because a lot of times transportation is a huge issue because of the roads. And I'll provide all that. We go to all the districts. So I say 'If you guys need us to do anything just let us know'. Just yesterday I was in Fora City ... So, I think it has really been beneficial to us that we have [the leader] around. Because I know that my information that I am gathering is actually being used for something and it is not just being sucked into a vacuum. And not seeing any impact." (R86) 
In the perception of the team members that we interviewed, the increased level of information sharing helped them to better understand the scope of activities of their team colleagues. This had mainly two consequences: First, by being better able to assess the work and agenda of every agency, prejudices among team members (e.g., "the military only sits in their compounds") could be diminished. Second, the improved information flow led to reduced conflicts within the team caused by unplanned encounters between military and humanitarian players in the field.

Thus, the sharing of information is of crucial importance because it enables team members to stay up to date concerning recent developments in the team and to better understand the position of other members in the team. The more team members are informed about the aims, actions, and functions of other members, the clearer will be the picture that they have of their team; this, in turn, can be assumed to also promote the clarity of the group prototype (i.e., the possibility of discerning and describing the features defining essential properties of the group; Chattopadhyay et al., 2004). As others have argued, this clarity of the group prototype facilitates team identification (Tajfel \& Turner, 1986; Turner, Hogg, Oakes, Reicher, \& Wetherell, 1987).

"[The leaders are] always like constantly sending us documents, constantly keeping us up to date with any new information that is coming in. You know, they're really like the parent of the group. I would say they've done a good job." (R43)

\section{Discussion}

The aim of our study was to explore the followers' perspective and to scrutinize which leadership behaviors are perceived to be relevant for the development of team identification from the followers' point of view. A possible gain that we expected from our analysis was the identification of leadership behaviors that had not been considered by extant research. Based on qualitative data from members of seven teams in the context of UN peacebuilding operations, we inductively derived four aggregate leadership dimensions that comprise a total of nine leadership behaviors: "providing guidance" (associated leadership behaviors: clarifying team goals, highlighting team boundaries, directing members), "encouraging involvement" (listening to team, advocating for team), "role modeling" (leading by example, addressing and motivating team), and "administering teamwork" (organizing meetings, facilitating information flow).

\subsection{Theoretical implications}

\subsubsection{Contribution to extant research}

Previous research has found charismatic and transformational leadership to be conducive to members' team identification (e.g., Kearney \& Gebert, 2009). Moreover, the study by Sivunen (2006) has inductively derived four "leadership tactics" promoting team identification from qualitative interviews with leaders in virtual teams (i.e., catering for the individual, giving positive feedback, bringing out common team goals, talking up team activities and face to face meetings). The results of our analysis both confirm and extend the findings of these studies.

Our study supports extant research in three ways. First, three of the inductively derived leadership behaviors from our analysis show similarities with theories of charismatic and transformational leadership (Bass \& Riggio, 2006). While "leading by example" corresponds with the transformational leadership dimension "idealized influence", "clarifying team goals" and "addressing and motivating team" resemble transformational leaders' "inspirational motivation" (Bass, 1985; Bass \& Avolio, 1994). In particular these two dimensions of transformational leadership have been discussed as triggers of followers' social identification (Kark \& Shamir, 2002; Shamir et al., 1993; Wu et al., 2010).

Second, the results of our analysis reveal some congruence with the findings from the qualitative study by Sivunen (2006). Among other things, she stressed the importance of individually caring and nurturing leadership behaviors, that is, paying attention to followers' needs and opinions. In a similar vein, our analysis found a leader's capacity to listen to and take up suggestions from the team ("listening to team") to be conducive to team identification. Moreover, Sivunen (2006) illustrated the relevance of leaders bringing out common team goals which reflects the leadership behavior "clarifying team goals" that was perceived to promote team identification by the interviewees in our sample.

Third, in addition to existing empirical studies, theorizing on the social identity model of leadership (van Knippenberg \& Hogg, 2003) emphasizes the importance of group oriented leadership. The proposed positive impact of group oriented leadership on members' team identification is also confirmed by our findings which stress the importance of exemplary group oriented conduct on the part of the leader (i.e., "leading by example").

In addition to corroborating existing research, our study identified several leadership behaviors relevant for team identification that had not been considered before. This pertains, first, to the provision of structural guidance to team members by means of "highlighting team boundaries". In addition to the strategic/goal oriented guidance which is also emphasized by theories of charismatic and transformational leadership, leadership behaviors aimed at emphasizing a team's boundaries contributed to achieving internal cohesion and a common feeling of belonging to the team. By providing team members with the possibility of differentiation vis à vis other teams and team external actors, leaders may have fueled members' in and out group categorizations and their identification with the team as the in group.

Second, we identified "advocating for the team" as another leadership behavior that has not been considered so far. Here it proved to be particularly conducive to members' team identification when leaders stood up for their team and fought for its interests vis à vis team external actors. Hence, also leadership aimed at the team external sphere had a positive spillover effect on members' team identification. 
Third, the findings of our analysis point to the complementarity of directive or even "authoritarian" leadership behaviors (e.g., "directing members") on the one hand and more "democratic" or participative leadership behaviors (e.g., "listening to team") on the other. While especially the former have not been included in prior analyses, it seems to be an interesting pattern of findings that both leadership behaviors contribute to the development of followers' team identification. In the course of our fieldwork, it emerged that directive leadership behaviors are particularly effective for facilitating members' team identification in early stages of the identification process (i.e., when a team is newly established or a team member first enters a team). By contrast, participative leadership appeared to play a crucial role for later developmental stages of members' team identification (i.e., when their team tenure increases). However, even though we placed a special emphasis on a narrative account for capturing the temporal nature of the identification process, our analysis is built on cross sectional data, thus making this finding tentative at best. Therefore, we believe that future quantitative and longitudinal research could contribute to a better understanding of the complementarity of different leadership behaviors in different developmental stages of team identification, in particular with regard to directive and participative leadership.

Fourth, our qualitative analysis revealed a number of leadership behaviors conducive to team identification that might appear rather commonplace as compared to leadership aspects typically investigated by quantitative studies (e.g., vision or charisma; Gardner et al., 2010). As Bryman (2004, p. 753) has pointed out, "qualitative researchers [...] also make clear the significance of more mundane instrumental forms of behavior, such as ensuring the need for adequate resources for followers to get the job done." For instance, taking charge of administrative and technical issues concerning teamwork (i.e., "organizing meetings" and "facilitating information flow") emerged to be of considerable importance in our analysis; that is, our interviewees perceived smooth and effective teamwork to facilitate their team identification. We believe that this finding is far from being trivial; by contrast, we are convinced that considering both extraordinary leader activities like visionary or charismatic leadership and everyday leadership behaviors is the key for gaining a better understanding of effective leadership for team identification.

To sum up, the exploration of the followers' perspective on the nexus of leadership and team identification in our analysis has broadened the range of leadership behaviors perceived to be relevant for team identification. Whereas extant research has exclusively focused on transformational/charismatic and rather participative leadership behaviors, the followers in our study also perceived more directive forms of leadership to be conducive to their team identification, as well as leadership behaviors pertaining to administrative or managerial aspects of teamwork. Finally, leadership aimed not only at team internal aspects but also at the team external sphere (with regard to both differentiating and fighting for the team vis à vis team external actors) was perceived to have a positive spillover effect on members' team identification. Due to the limited scope of a single empirical study like this, we cannot warrant that the whole spectrum of leadership behaviors relevant for team identification has been explored by our analysis. However, we are convinced that our study covers a considerable part of this spectrum, in particular due to the broad range of follower perspectives resulting from the huge diversity of our sample.

\subsubsection{Further implications}

To begin with, the results from our interviews reveal considerable complexity with regard to how our respondents perceived leadership to affect their feeling of belonging and attachment to the team. Instead of directly relating certain leadership behaviors to team identification, many of our interviewees referred to improved team processes and functioning when illustrating how they considered leadership to influence their feeling of belonging to the team. Thus, our analysis points to the need for studying more complex relationships: For example, while existing research has shown leadership to be positively related to team performance (e.g., DeRue, Nahrgang, Wellman, \& Humphrey, 2011) and team performance to foster team identification (e.g., Dutton et al., 1994), mediation models between leadership, team processes, outcomes, and team identification have been largely neglected. We believe that scrutinizing mediators and moderators of the relationship between leadership and team identification constitutes an exciting avenue for future research.

In addition, a number of scholars in the field of shared leadership and self managing teams have argued that the existence of a formally designated leader (Morgeson et al., 2010) is often not necessary for effective team processes and high team performance (e.g., Carson, Tesluk, \& Marrone, 2007; Langfred, 2004). However, the findings of this study rather point towards the importance of formally assigned leaders for fostering team identification as perceived by the individuals becoming identified (i.e., the followers). This might be particularly important in situations of high ambiguity and complexity, such as the setting in which our research took place. Hence, future research on leadership and team identification might benefit from more comparative approaches that are better able to capture the differences pertaining to the development of team identification in teams with shared vs. non shared leadership. In this regard, experimental research may prove useful for investigating the effectiveness of both kinds of leadership for promoting team identification.

Moreover, the results of this study contradict the notion that only collective oriented leadership behaviors contribute to the development of team identification (e.g., Kark \& Shamir, 2002; Kark et al., 2003). Rather, our findings indicate that both collective and individual oriented leadership behaviors were perceived to be relevant for strengthening team identification by the individuals in our sample. Leadership behaviors aimed at helping individuals in defining their own and others' roles and responsibilities in a team play a crucial role for team members' sensemaking and consequently strengthen their identification with the work group. Thus, individual oriented leadership seems to be just as important as collective oriented leadership. In order to further consolidate this finding, future quantitative research might examine the effects of individual oriented leadership on team identification.

Finally, the prominent role that leaders appeared to play for the development of team identification in our sample may also entail a peril. That is, if the leader serves as the major promoter of identification in the team (or as a "parent to the group" as one respondent has termed it), this contains the risk of dependency on the leader. In particular in Team F, an interviewee expressed the fear that their team would disintegrate if the leader was leaving. It thus appears to be possible that instead of empowering the development of team 
identification among team members, leaders may also become indispensable parts of this development process. Moreover, it is possible that the team members identify with the leader as some kind of "hallmark" of their team rather than with the team itself. It is particularly interesting that we found hints for possible dependency effects with regard to our aggregate leadership dimension "providing guidance" which shows some similarities with charismatic and transformational leadership. Existing research has already found evidence for the risk of cognitive and motivational dependency on transformational leaders (e.g., Eisenbeiss \& Boerner, 2013; Kark et al., 2003). Further research is necessary for illuminating possible negative effects of leadership with regard to team identification.

\subsection{Managerial implications}

Due to the exploratory nature of the research design and the small sample size, the derivation of practical implications from our analysis is limited. However, there are several aspects that may be of particular interest for fostering team identification through team leadership and that should therefore be mentioned. First, even though the importance of self management in teams is often emphasized (e.g., Kirkman \& Rosen, 1999), the results of our study imply that leadership may play a pivotal role for the promotion of team identification. This suggests that organizations should not uncritically rely on shared leadership for promoting team identification, especially when it is intended for overcoming cooperation problems in teams (team identification as "social glue"; van Vugt \& Hart, 2004, p. 585).

Second, some of the leadership behaviors that proved to be beneficial for the development of team identification in previous quantitative research have been confirmed by the exploratory analysis in this study. Thus, leadership trainings aimed at preparing leaders for promoting team identification should especially focus on aspects of transformational and group oriented leadership (van Knippenberg \& Hogg, 2003; Walumbwa et al., 2008). That is, leaders should for instance become aware of the fact that group oriented attitudes and behaviors (e.g., showing commitment to or going an extra mile for the team) are particularly important since leaders serve as role models for team members.

Third, the complementary effects of different leadership behaviors for team identification constitute a major challenge for team leaders. Given the fact that many teams are characterized by frequent changes in their composition, different team members are likely to pass through different stages of the identification process at a particular point in time. Since there was initial evidence in our study that different leadership behaviors are more or less appropriate for different stages in the process of developing team identification, team leaders are required to individually differentiate their leadership behavior according to the developmental stage each individual team member is passing through. Organizational leadership training should thus place a major emphasis on the simultaneous application of different leadership behaviors, for instance directive and participative leadership.

\subsection{Limitations and outlook}

Apart from the implications for theory and managerial practice, there are also several limitations to our analysis. To begin with, even though the aim of this study was to explore the followers' perspective on leadership and team identification, this approach may also have caused biases in our findings (Kelley, 1971; Martinko, Harvey, \& Douglas, 2007; Pfeffer, 1977). By exclusively relying on the followers' perspective, we have taken their implicit causal assumptions concerning the linkage of leadership behaviors and team identification for granted. However, research on attribution processes in leadership contexts posits that for reasons of cognitive complexity reduction, individuals attribute responsibility for organizational outcomes to their leaders, rather than taking into account other possible factors (Bligh, Kohles, \& Pillai, 2011; Meindl, Ehrlich, \& Dukerich, 1985). With regard to our study, the exclusive reliance on the followers' perspective thus entails the risk of an attribution error as the followers may attribute the outcome (i.e., strong team identification) to the leader rather than to the situation (e.g., the dynamic environment in which the UN teams operate).

By exclusively focusing on the followers' perspective, our analysis is to a certain extent related to research that presents leadership as cognitively constructed by followers (e.g., Lord, Foti, \& De Vader, 1984; Meindl et al., 1985). In this regard, Shamir (2007) identifies several other follower centric research traditions (e.g., studies that examine follower characteristics as moderators of leader impact; Hersey \& Blanchard, 1977). Unfortunately, due to the limited access to the followers in our exceptional field setting, we were not able to gather even more fine grained data and thus cannot contribute to other follower centric research traditions. For instance, we think it would constitute an exciting avenue for future research to identify meaningful variations in follower characteristics that moderate the impact of leadership on team identification (e.g., Pierro et al., 2005).

Another limitation of our study is that, due to our qualitative and exploratory research approach, we cannot preclude that the leadership behaviors inductively derived in our study show some conceptual overlap. Yet, we are convinced that each leadership behavior reflects a unique aspect of leaders' interventions, in particular due to our very careful data analysis and the consolidation of the exemplary incidents and quotes from our data by two researchers independently from each other. During the coding and the categorization of the leadership behaviors that surfaced in our interviews, the two involved researchers identified only a small amount of quotes that could not unequivocally be assigned to one of the inductively derived leadership behaviors (approx. 10 15\%). Thereby, most of the ambiguous quotes pertained to leadership behaviors within the same aggregate leadership dimension; thus it can be concluded that our findings are particularly robust at the level of the aggregate leadership dimensions. The only quotes that showed interrelationships across different aggregate leadership dimensions were those that pertained to leaders' exemplary conduct. Here, some quotes that were essentially related to, for instance, advocating for the team or addressing and motivating team members sometimes also contained references to leaders' "exemplary" behavior. However, by making the inductively derived categories of leadership behavior as specific as possible, we are confident that also on the level of the leadership behaviors our findings show conceptual distinctiveness. Anyway, due to our qualitative research approach, we do not pretend perfect conceptual distinctiveness to 
be the ultimate goal of our analysis. The construct validity of our proposed categorization can only be tested in quantitative follow up studies operationalizing the proposed leadership behaviors and analyzing them with the help of factor analysis.

Finally, the analysis and findings presented in this paper are subject to a number of limitations that are common for qualitative case study research (Eisenhardt, 1989). First, the sample of our study is rather small, thereby impairing the overall generalizability of our findings. This is mainly due to our goal to provide in depth insights into the followers' perspective on leadership and team identification which is only feasible based on a limited number of subjects of analysis (Yin, 2003). Second, our analysis is based on cross sectional data, hence limiting the ability to make causal assertions. Ideally, we would have been able to conduct a longitudinal study observing the change in members' team identification over time; however, given the restraints on research resources, the potentially dangerous setting of our sample, and the limited field time, we had to rely on team members' retrospective accounts on the role of leadership for the development of team identification. Third, even though UN peacebuilding teams constitute a qualified and exciting setting for studying the influence of leadership on team identification, we cannot preclude that the empirical setting may have influenced our pattern of findings. UN led peacebuilding operations are complex undertakings with very ambitious goals that are usually achieved under high public pressure in mostly unpredictable environments. Hence, we cannot rule out that specific traits of our setting have affected the way in which the observed leadership behaviors have unfolded their impact on team identification.

Nevertheless we are convinced that this study can serve as a good starting point for future research. In addition to some of the possible avenues for future research outlined above, several recommendations can be made. First, the exploratory findings of this analysis should be subject to large scale quantitative empirical testing in near future. This would allow for further validating the insights gained by this study and deriving more generalizable results. Second, future studies would benefit from longitudinal research designs for investigating whether the effectiveness of different leadership behaviors is contingent on the stage of the identification process that team members are passing through. Third, exploring contingency factors of different leadership behaviors for promoting team identification also appears to be an exciting avenue for future research. And finally, future research may explore the possible role of leadership for members' disidentification with their team (Kreiner \& Ashforth, 2004). While our investigation has focused on strengthening followers' team identification, it also appears to be possible that leadership impedes the development of team identification or even leads to the rejection of any kind of association with the team.

\section{Appendix A}

Table A1

Leadership in teams - Aggregate leadership dimensions (ALD), Leadership behaviors (LB), and illustrations.

\begin{tabular}{|c|c|c|}
\hline ALD & LB & Illustrations \\
\hline \multirow[t]{8}{*}{$\begin{array}{l}\text { Providing } \\
\text { guidance }\end{array}$} & \multirow[t]{2}{*}{ Clarifying team goals } & $\begin{array}{l}\text { "The first time members of the team were exposed to the strategic guidance was when we had a team } \\
\text { leader" (R122) }\end{array}$ \\
\hline & & $\begin{array}{l}\text { "But I was trying to answer your question with respect to there being clarity on where exactly we fit in as a } \\
\text { [team]. That might not necessarily have been there before we had a leader" (R122) } \\
\text { "I think first and foremost for a team to work effectively the chair or convener has to be very, very clear as } \\
\text { to what it is set up to achieve" (R75) }\end{array}$ \\
\hline & \multirow[t]{3}{*}{$\begin{array}{l}\text { Highlighting team } \\
\text { boundaries }\end{array}$} & $\begin{array}{l}\text { "Well, number one is strong leadership. I think it is a strong leader who has this ability to build a team and to } \\
\text { give this sense to people that they belong to a team" (R77) }\end{array}$ \\
\hline & & $\begin{array}{l}\text { "I also strongly believe that there should be a leader as I don't want our specificity to be washed out by the } \\
\text { others" (R89) }\end{array}$ \\
\hline & & $\begin{array}{l}\text { "It was [the leader], yes, he was the person who believed in it, you know... And when he left ... the group } \\
\text { died" (R31) }\end{array}$ \\
\hline & \multirow[t]{3}{*}{ Directing members } & $\begin{array}{l}\text { "It is very important that there is proper guidance provided to members of the [team], for them to be able to do } \\
\text { the work of the [team] the way it ought to be done, rather than leave it to themselves to do trial and error and } \\
\text { somehow find their way" (R122) }\end{array}$ \\
\hline & & $\begin{array}{l}\text { "He would actually shake everybody else and say 'look, we've got to do this and we've got to do that and } \\
\text { we said we're going to do this, can we meet the deadline?' and so on. And things are going well now } \\
\text { [in the team]" (R100) }\end{array}$ \\
\hline & & $\begin{array}{l}\text { "It is good to have like someone who [leader] she came from a military background. So she had a good like } \\
\text { command attitude and behavior. She was not like the soft kind of person that would sit down and lay back } \\
\text { and 'OK, who has any ideas?"' (R77) }\end{array}$ \\
\hline \multirow[t]{7}{*}{$\begin{array}{l}\text { Encouraging } \\
\text { involvement }\end{array}$} & \multirow[t]{4}{*}{ Listening to team } & $\begin{array}{l}\text { "I guess [the leader] realized it was important for us to pretty much understand our own role, it was important } \\
\text { to give each member this tool [the possibility to voice your opinion]" (R30) }\end{array}$ \\
\hline & & $\begin{array}{l}\text { "And so when you work with [the leader], you are invited to give ideas, you can propose, you can say what you } \\
\text { think can be more useful, you know, to help the [the team] carry out its mission and to fulfill its objectives in } \\
\text { Haiti" (R91) }\end{array}$ \\
\hline & & Interviewer: "You think that your voice or your opinion or your perspective is being heard by the [leader]?" \\
\hline & & Respondent: "By the [leader], yes, Yes, yes, totally. Without any discussion" (R19) \\
\hline & \multirow{3}{*}{$\begin{array}{l}\text { Addressing and } \\
\text { motivating team }\end{array}$} & "Selling the idea and engaging everybody in this issue is really key and important [for leadership]" (R116) \\
\hline & & $\begin{array}{l}\text { "Actively the [the leader] has succeeded in mobilizing almost all of the agencies to the extent where everyone } \\
\text { participates. In meetings and working sessions that are called" (R38) }\end{array}$ \\
\hline & & $\begin{array}{l}\text { "The [leader] was very strong... She used to look for the people. She got them and made sure they came } \\
\text { here and she did all the meetings that had to be done. It is a lot of work" (R132) }\end{array}$ \\
\hline
\end{tabular}




\begin{tabular}{|c|c|c|}
\hline ALD & LB & Illustrations \\
\hline \multirow[t]{2}{*}{ Role modeling } & Leading by example & $\begin{array}{l}\text { "[The leaders] show you the interest to really try to work together as a team, to communicate, to show } \\
\text { commitment to the team's objectives" (R26) } \\
\text { "And the leadership is ... a person who is very involved, not just as a job ... but truly ... you feel the } \\
\text { engagement, not just the compassion wanting things to happen, he is very committed to not only doing his } \\
\text { job but making Haiti become more structured in their national response to the [topic]" (R133) } \\
\text { "When there is a [leader] that, you know, doesn't put his or her ambition or program or views beyond that } \\
\text { organization he or she's working with ... [it's a problem]" (R63) }\end{array}$ \\
\hline & $\begin{array}{l}\text { Advocating for the } \\
\text { team }\end{array}$ & $\begin{array}{l}\text { "[The team's topic] was absolutely not a part of this document and I think being able to discuss, the coordinator } \\
\text { was used to do that and he really advocated [for the team]" (R32) } \\
\text { "This struggle [for feeling like a team] in the [team] was mainly then resolved by the head putting, let's say the } \\
\text { right incentives in place for the members of the group in terms of raising awareness with agency heads and } \\
\text { prompting agency heads to go after their people to attend the meeting" (R } 53 \text { ) } \\
\text { "But now the [leader] has to... [go to senior leadership] and it makes a difference. Because sometimes they } \\
\text { have to devote time to go and meet the [senior leader] and to inform [him] and to sell the idea and whatever } \\
\text { and to convince them to put some money on this activity and so it makes a difference." (R116) }\end{array}$ \\
\hline \multirow[t]{2}{*}{$\begin{array}{l}\text { Administering } \\
\text { teamwork }\end{array}$} & Organizing meetings & $\begin{array}{l}\text { "And also the role of the [the leader] chairing the meeting is critical, calling for meetings on time, or following } \\
\text { up on resolutions or actions that have been agreed upon. This made us more effective [.... ] and eventually you } \\
\text { know we began to appreciate it [the team's work]" (R135) } \\
\text { "I am actually ... I am excited to go to these meetings because ... I guess it goes hand in hand with what I said } \\
\text { about management itself because we have an agenda and a follow agenda, we have action items for specific } \\
\text { people at the end of the meeting, we have ... everyone knows their role and it is very specific. We get } \\
\text { accomplishment. We get effective." (R86) } \\
\text { "But [the leader] was very good like in a very structured way. For example; in a meeting it is very good if you } \\
\text { already have a structure of the meeting. And you follow the structure, the agenda. And the agenda points are } \\
\text { actually relevant to the work of the people. And in those meetings we always had a good agenda and were not } \\
\text { wasting time with useless discussions" (R77) }\end{array}$ \\
\hline & $\begin{array}{l}\text { Facilitating information } \\
\text { flow }\end{array}$ & $\begin{array}{l}\text { "And we have our [team leader] who reports there and who brings back whatever has been said and is relevant } \\
\text { to the group" (R100) } \\
\text { "And ensuring as you move along you have periodic updates so that people know how far they are going and it } \\
\text { is not to query any agency but just to know the status of the implementation of what was agreed on" (R75) } \\
\text { "But after the meeting, [the leader] asked me to stay and we spent about an hour to teach me about the process, } \\
\text { to inform me about what [the other team members] were doing. So this helped me to better understand what } \\
\text { the team was all about" (R134) }\end{array}$ \\
\hline
\end{tabular}

\section{References}

Ashforth, B. E., Harrison, S. H., \& Corley, K. G. (2008). Identification in organizations: An examination of four fundamental questions. Journal of Management, 34(3), $325-374$.

Ashforth, B. E., \& Johnson, S. A. (2001). Which hat to wear? The relative salience of multiple identities in organizational contexts. In M. A. Hogg, \& D. J. Terry (Eds.), Social Identity Processes in Organizational Contexts (pp. 31-48). Philadelphia, PA: Psychology Press.

Ashforth, B. E., \& Mael, F. A. (1996). Organizational identity and strategy as a context for the individual. Advances in Strategic Management, 13(1), 17-62.

Avolio, B. J., Walumbwa, F. O., \& Weber, T. J. (2009). Leadership: Current theories, research, and future directions. Annual Review of Psychology, 60, 421-449.

Bass, B. M. (1985). Leadership and Performance Beyond Expectations. New York: Free Press.

Bass, B. M., \& Avolio, B. J. (1994). Improving Organizational Effectiveness Through Transformational Leadership. Thousand Oaks, CA: Sage.

Bass, B. M. \& Riggio, R. E. (2006). Transformational Leadership. Mahwah, NJ: Erlbaum.

Bergami, M, \& Bagozzi, R. P. (2000). Self-categorization, affective commitment and group self-esteem as distinct aspects of social identity in the organization. British Journal of Social Psychology, 39(4), 555-577.

Bezrukova, K., Jehn, K. A. Zanutto, E. L, \& Thatcher, S. M. B. (2009). Do workgroup faultlines help or hurt? A moderated model of faultlines, team identification, and group performance, Organization Science, 20(1), 35-50.

Bligh, M. C. (2011). Followership and follower-centered approaches. In A. Bryman, D. Collinson, K. Grint, B. Jackson, \& M. Uhl-Bien (Eds.), The Sage Handbook of Leadership (pp, 423-434). London; Sage.

Bligh, M. C., Kohles, J. C., \& Pillai, R. (2011), Romancing leadership: Past, present, and future. The Leadership Quarterly, 22(6), $1058-1077$.

Branscombe, N. R., Ellemers, N., Spears, R., \& Doosje, B. (1999). The context and content of social identity threat. In N. Ellemers, R. Spears, \& B. Doosje (Eds.), Social Identity: Context, Commitment, Content (pp. 35-58). Oxford: Blackwell.

Brewer, M. (1991). The social self: On being the same and different at the same time. Personality and Social Psychology Bulletin, 17(5), 475-482.

Brewer, M. B., \& Gardner, W. (1996). Who is this 'we'? Levels of collective identity and self-representations. Journal of Personality and Social Psychology, 71(1), $83-93$.

Bryman, A. (2004). Qualitative research on leadership: A critical but appreciative review. The Leadership Quarterly, 15(6), 729-769.

Carson, J. B., Tesluk, P. E., \& Marrone,J. A. (2007). Shared leader ship in teams: An investigation of antecedent conditions and performance, Academy of Management Journal, 50 (5), 1217-1234.

Carsten, M. K., \& Bligh, M. C. (2007). Here today, gone tomorrow: Follower perceptions of a departing leader and a lingering vision. In B. Shamir, R. Pillai, M. C. Bligh, \& M. Uhl-Bien (Eds.), Follower-centered Perspectives on Leadership - A Tribute to the Memory of James R. Meindl (pp. 211-242). Greenwich: CT: Information Age Publishing

Chattopadhyay, P., George, E., \& Lawrence, S. A. (2004). Why does dissimilarity matter? Exploring self-categorization, self-enhancement, and uncertainty reduction, Journal of Applied Psychology, 89(5), 892-900.

Cicero, L., Pierro, A., \& van Knippenberg, D. (2007). Leader group prototypicality and job satisfaction: The moderating role of job stress and team identification. Group Dynamics: Theory, Research, and Practice, 11(3), 165-175.

Conger, J. A., Kanungo, R. N., \& Menon, S. T. (2000). Charismatic leadership and follower effects, Journal of Organizational Behavior, 21 (7), $747-767$.

Corbin, J., \& Strauss, A. L (2008). Basics of Qualitative Research (3rd ed.)London: Sage.

Cregan, C, Bartram, T., \& Stanton, P. (2009). Union organizing as a mobilization strategy: The impact of social identity and transformational leadership on the collectivism of union members, British Journal of Industrial Relations, 47(4), 701-722. 
De Cremer, D., \& van Knippenberg, D. (2002). How do leaders promote cooperation? The effects of charisma and procedural fairness. Journal of Applied Psychology, $87(5), 858-866$

De Vaus, D. (2001). Research Design in Social Research. London: Sage.

DeRue, D. S., Nahrgang, J. D., Wellman, N., \& Humphrey, S. E. (2011). Trait and behavioral theories of leadership: An integration and meta-analytic test of their relative validity. Personnel Psychology, 64(1), 7-52.

Dutton, J. E., \& Dukerich, J. M. (1991). Keeping an eye on the mirror: Image and identity in organizational adaptation. Academy of Management Journal, 34(3), 517-554.

Dutton, J. E., Dukerich, J. M., \& Harquail, C. V. (1994). Organizational images and member identification. Administrative Science Quarterly, 39(2), 239-263.

Edwards, M. R., \& Peccei, R. (2007). Organizational identification: Development and testing of a conceptually grounded measure. European Journal of Work and Organizational Psychology, 16(1), 25-57.

Eisenbeiss, S. A., \& Boerner, S. (2013). A double-edged sword: Transformational leadership and individual creativity. British Journal of Management, 24(1), 54-68.

Eisenhardt, K. M. (1989). Building theory from case study research. Academy of Management Review, 14(4), 532-550.

Elsbach, K. D., \& Kramer, R. M. (1996). Members' responses to organizational identity threats: Encountering and countering the Business Week rankings. Administrative Science Quarterly, 41(3), 442-476.

Fiol, C. M., \& O'Connor, E. J. (2005). Identification in face-to-face, hybrid, and pure virtual teams: Untangling the contradictions. Organization Science, 16(1), 19-32.

Frerks, G., Klem, B., Laar, S. v, \& Klingeren, M. v (2006). Principles and pragmatism: Civil-military action in Afghanistan and Liberia. Working paper. Utrecht University, NL.

Gardner, W. L., Lowe, K. B., Moss, T. W., Mahoney, K. T., \& Cogliser, C. C. (2010). Scholarly leadership of the study of leadership: A review of The Leadership Quarterly's second decade 2000-2009. The Leadership Quarterly, 21(6), 922-958.

Glaser, B. G., \& Strauss, A. L. (1967). The Discovery of Grounded Theory: Strategies for Qualitative Research. Chicago: Aldine.

Grieve, P. G., \& Hogg, M. A. (1999). Subjective uncertainty and intergroup discrimination in the minimal group situation. Personality and Social Psychology Bulletin, $25,926-940$.

Hersey, P., \& Blanchard, K. H. (1977). Management of Organizational Behavior: Utilizing Human Resources (3rd ed.)Englewood Cliffs, NJ: Prentice Hall.

Hogg, M. A., \& Hains, S. C. (1996). Intergroup relations and group solidarity: Effects of group identification and social beliefs on depersonalized attraction. Journal of Personality and Social Psychology, 70(2), 295-309.

Hogg, M. A., \& Terry, D. J. (2000). Social identity and self-categorization processes in organizational contexts. Academy of Management Review, 25(1), 121-140.

Joshi, A., Lazarova, M. B., \& Liao, H. (2009). Getting everyone on board: The role of inspirational leadership in geographically dispersed teams. Organization Science, 20(1), 240-252.

Joshi, A., \& Roh, H. (2009). The role of context in work team diversity research: A meta-analytical review. Academy of Management Journal, 52(3), 599-627.

Kark, R., \& Shamir, B. (2002). The dual effect of transformational leadership: Priming relational and collective selves and further effects on followers. In B. J. Avolio, \& F. J. Yammarino (Eds.), Transformational and Charismatic Leadership: The Road Ahead (pp. 67-91). Amsterdam: JAI.

Kark, R., Shamir, B., \& Chen, G. (2003). The two faces of transformational leadership: Empowerment and dependency. Journal of Applied Psychology, 88(2), $246-255$.

Kearney, E., \& Gebert, D. (2009). Managing diversity and enhancing team outcomes: The promise of transformational leadership. Journal of Applied Psychology, 94(1), 77-89.

Kelley, H. H. (1971). Attributions in Social Interaction. New York: General Learning Press.

King, G., Keohane, R. O., \& Verba, S. (1994). Designing Social Inquiry. Scientific Inference in Qualitative Research. Princeton, NJ: Princeton University Press.

Kirkman, B. L., \& Rosen, B. (1999). Beyond self-management: Antecedents and consequences of team empowerment. Academy of Management Journal, 42(1), $58-74$.

Kreiner, G., \& Ashforth, B. E. (2004). Evidence towards an expanded model of organizational identification. Journal of Organizational Behavior, $25(1), 1-27$.

Kvale, S. (1996). InterViews: An Introduction to Qualitative Research Interviewing. Thousand Oaks, CA: Sage.

Langfred, C. W. (2004). Too much of a good thing? Negative effects of high trust and individual autonomy in self-management teams. Academy of Management Journal, 47(3), 385-399.

Leech, B. L. (2002). Asking questions: Techniques for semistructured interviews. PS: Political Science and Politics, 35(4), 665-668

Locke, K. (2001). Grounded Theory in Management Research. Thousand Oaks, CA: Sage.

Lord, R. G., \& Brown, D. J. (2004). Leadership Processes and Follower Self-identity. Mahwah, NJ: Erlbaum.

Lord, R. G., Brown, D. J., \& Freiberg, S. J. (1999). Understanding the dynamics of leadership: The role of follower self-concepts in the leader/follower relationship. Organizational Behavior and Human Decision Processes, 78(3), 167-203.

Lord, R. G., Foti, R. J., \& De Vader, C. L. (1984). A test of leadership categorization theory: Internal structure, information processing, and leadership perceptions. Organizational Behavior and Human Performance, 34(3), 343-378.

Mael, F., \& Ashforth, B. E. (1992). Alumni and their alma mater: A partial test of the reformulated model of organizational identification. Journal of Organizational Behavior, 13(2), 103-124.

Martinko, M. J., Harvey, P., \& Douglas, S. C. (2007). The role, function, and contribution of attribution theory to leadership: A review. The Leadership Quarterly, 18(6), 561-585.

Meindl, J. R., Ehrlich, S. B., \& Dukerich, J. M. (1985). The romance of leadership. Administrative Science Quarterly, 30(1), 78-102.

Miles, M. B., \& Huberman, A. M. (1994). Qualitative Data Analysis: An Expanded Sourcebook (2nd ed.)Thousand Oaks, CA: Sage.

Morgeson, F. P., DeRue, D. S., \& Karam, E. P. (2010). Leadership in teams: A functional approach to understanding leadership structures and processes. Journal of Management, 36(1), 5-39.

Oh, H., Chung, M. -H., \& Labianca, G. (2004). Group social capital and group effectiveness: The role of informal socializing ties. Academy of Management Journal, $47(6), 860-875$.

Patton, M. Q. (1990). Qualitative Evaluation and Research Methods (2nd ed.)Newbury Park, CA: Sage.

Paul, J., Costley, D. L., Howell, J. P., Dorfman, P. W., \& Trafimow, D. (2001). The effects of charismatic leadership on followers' self-concept accessibility. Journal of Applied Social Psychology, 3(9), 1821-1844.

Pettigrew, A. M. (1990). Longitudinal field research on change: Theory and practice. Organization Science, 1(3), 267-292.

Pfeffer, J. (1977). The ambiguity of leadership. Academy of Management Review, 2(1), 104-112.

Pierro, A., Cicero, L., Bonaiuto, M., van Knippenberg, D., \& Kruglanski, A. W. (2005). Leader group prototypicality and leadership effectiveness: The moderating role of need for cognitive closure. The Leadership Quarterly, 16(4), 503-516.

Postmes, T., Haslam, S. A., \& Swaab, R. I. (2005). Social influence in small groups: An interactive model of social identity formation. European Review of Social Psychology, 16(1), 1-42.

Pratt, M. G. (1998). To be or not to be? Central questions in organizational identification. In D. A. Whetten, \& P. C. Godfrey (Eds.), Identity in Organizations: Building Theory Through Conversation (pp. 171-207). Thousand Oaks, CA: Sage.

Pratt, M. G. (2000). The good, the bad, and the ambivalent: Managing identification among Amway distributors. Administrative Science Quarterly, 45 (3), 456-493.

Pratt, M. G., Rockmann, K. W., \& Kaufmann, J. B. (2006). Constructing professional identity: The role of work and identity learning cycles in the customization of identity among medical residents. Academy of Management Journal, 49(2), 235-262.

Reicher, S., Haslam, S. A., \& Hopkins, N. (2005). Social identity and the dynamics of leadership: Leaders and followers as collaborative agents in the transformation of social reality. The Leadership Quarterly, 16(4), 547-568.

Riketta, M., \& van Dick, R. (2005). Foci of attachment in organizations: A meta-analytic comparison of the strength and correlates of workgroup versus organizational identification and commitment. Journal of Vocational Behavior, 67(3), 490-510.

Rockmann, K. W., Pratt, M. G., \& Northcraft, G. (2007). 'Divided loyalties': Determinants of identification in inter-organizational teams. Small Group Research, 38(6), 727-751. 
Rubin, H. J., \& Rubin, I. S. (2005). Qualitative Interviewing: The Art of Hearing Data. Thousand Oaks, CA: Sage.

Shamir, B. (2007). From passive recipients to active co-producers: Followers' roles in the leadership process. In B. Shamir, R. Pillai, M. C. Bligh, \& M. Uhl-Bien (Eds.), Follower-centered Perspectives on Leadership (pp. ix-xxxix). Greenwich: CT: Information Age Publishing.

Shamir, B., House, R. J., \& Arthur, M. B. (1993). The motivational effects of charismatic leadership: A self-concept based theory. Organization Science, 4(4), 577-594.

Shamir, B., Zakay, E., Breinin, E., \& Popper, M. (1998). Correlates of charismatic leader behaviour in military units: Subordinates' attitudes, unit characteristics, and superiors' appraisals of leader performance. Academy of Management Journal, 41(4), 387-409.

Shamir, B., Zakay, E., Breinin, E., \& Popper, M. (2000). Leadership and social identification in military units: Direct and indirect relationships. Journal of Applied Social Psychology, 30(3), 612-640.

Sivunen, A. (2006). Strengthening identification with the team in virtual teams: The leaders' perspective. Group Decision and Negotiation, 15(4), 345-366.

Spradley, J. S. (1979). The Ethnographic Interview. New York: Harcourt College Publishers.

Strauss, A. L., \& Corbin, J. (1990). Basics of Qualitative Research: Grounded Theory Procedures and Techniques. Thousand Oaks, CA: Sage.

Tajfel, H. (1978). Differentiation Between Social Groups: Studies in the Social Psychology of Intergroup Relations. London: Academic Press.

Tajfel, H., \& Turner, J. C. (1986). The social identity theory of intergroup behavior. In S. Worchel, \& W. G. Austin (Eds.), Psychology of Intergroup Relations (pp. 7-24). Chicago: Nelson Hall.

Turner, J. C., Hogg, M. A., Oakes, P. G., Reicher, S. D., \& Wetherell, M. S. (Eds.). (1987). Rediscovering the Social Group: A self-categorization Theory. Oxford: Blackwell. van der Vegt, G. S., \& Bunderson, J. S. (2005). Learning and performance in multidisciplinary teams: The importance of collective team identification. Academy of Management Journal, 48(3), 532-547.

van Knippenberg, D., \& Ellemers, N. (2003). Social identity and group performance: Identification as a key to collective effort. In S. A. Haslam, D. van Knippenberg M. Platow, \& N. Ellemers (Eds.), Social Identity at Work: Developing Theory for Organizational Practice (pp. 29-42). New York: Psychology Press.

van Knippenberg, D., \& Hogg, M. A. (2003). A social identity model of leadership effectiveness in organizations. Research in Organizational Behavior, 25, 243-295. van Knippenberg, D., van Knippenberg, B., De Cremer, D., \& Hogg, M. A. (2004). Leadership, self, and identity: A review and research agenda. The Leadership Quarterly, 15(6), 825-856.

van Knippenberg, D., van Knippenberg, B., De Cremer, D., \& Hogg, M. A. (2005). Research in leadership, self, and identity: A sample of the present and a glimpse of the future. The Leadership Quarterly, 16(4), 495-499.

van Vugt, M., \& Hart, C. M. (2004). Social identity as social glue: The origins of group loyalty. Journal of Personality and Social Psychology, 86(4), 585-598.

Walumbwa, F. O., Avolio, B. J., \& Zhu, W. (2008). How transformational leadership weaves its influence on individual job performance: The role of identification and efficacy beliefs. Personnel Psychology, 61(4), 793-825.

Webster, J., \& Wong, W. K. P. (2008). Comparing traditional and virtual group forms: Identity, communication, and trust in naturally occurring project teams. International Journal of Human Resource Management, 19(1), 41-62.

Wu, J. B., Tsui, A. S., \& Kinicki, A. J. (2010). Consequences of differentiated leadership in groups. Academy of Management Journal, 53(1), 90-106.

Yin, R. K. (2003). Case Study Research: Design and Methods (3rd ed.)Newbury Park, CA: Sage.

Yukl, G. A. (2010). Leadership in Organizations (7th ed.)Upper Saddle River, NJ: Pearson Prentice Hall. 